not adversely affect plant size or time to flowering, applications of this fungicide should be made in rotation with other fungicides to avoid selection and build-up of fungicide-resistant pathogen populations.

In addition, this study effectively identified fenaminosulf fungicide drenching schedules that consistently reduced plant size and delayed time to flowering among seedpropagated geraniums. Although only existing supplies of fenaminosulf are still available to growers, it is important for them to recognize that an alternate product, such as metalaxyl, can not only be more effective (Hausbeck et al., 1988) but also less phytotoxic. Further, the inclusion of fenaminosulf in this study has shown that fungicide drenches applied to healthy geraniums may "cost" a grower in terms of reduced plant size and delayed time to flowering. Also, results suggest specific plant growth stages may be particularly sensitive to fungicide drenches. Based on this study, similar investigations conducted with additional fungicides and crops appear to be warranted. This information is necessary to make recommendations concerning fungicide usage complete.

\section{Literature Cited}

Bewley, W.F. and W. Buddin. 1921. On the fungus flora of glasshouse water supplies in relation to plant disease. Ann. Appl. Biol. 8:1019.

Boodley, J.W. 1968. Poinsettia propagation and fungicides. N.Y. State Flower Growers Bul. 274:4-5.

Gill, D.L. 1970. Pathogenic Pythium from irrigation ponds. Plant Dis. Rptr. 54:1077-1079.

Hausbeck, M. K., C.T. Stephens, and R.D. Heins. 1987. Variation in resistance of geranium to Pythium ultimum in the presence or absence of silver thiosulphate. HortScience 22:940-944.

Hausbeck, M. K., C.T. Stephens, and R.D. Heins. 1988. Control of disease caused by Pythium ultimum in seed-propagated geraniums sprayed or not sprayed with silver thiosulfate. Plant Dis. 72:764-768

Hausheck, M. K., C.T. Stephens, and R.D. Heins. 1989a. Damping-off, root rot, and lower stem rot of seed-propagated geraniums caused by Pythium ultimum. Plant Dis. 73:625-27.

Hausbeck, M. K., C.T. Stephens, and R.D. Heins. 1989b. Relationship between silver thiosulfate and premature plant death of seed-propagated geraniums caused by Pyhium ultimum. Plant Dis. 73:627-630

Kuack, D. L., H.K. Tayama, J.C. Peterson, and P.A. Fracasso. 1981. Effect of various fungicides on the rooting of poinsettias, cv. 'Annette Hegg Dark Red'. Ohio Florist's Assn. Bul. 620.

Lee, W. L., K.C. Sanderson, and J.G. Williams. 1983. Effect of fungicides applied to polyurethane propagation blocks on rooting of poinsettia cuttings. HortScience 18:359-360,

Manning, W.J.,. F.J. Campbell, and M. Glickman. 1969. Effects. of fungicide drenches on established poinsettia plants. Plant Dis. Rptr. 53:225-227.

Moonnan, G.W. 1983. Effect of fungicide drenches on root initiation by geranium cuttings. Plant Dis. 67:612-613.

Powell, C.C. 1982. Diseases of seedling geraniums, p. 262-265. In: J.W. Mastalerz and E.J. Holcomb (eds.). Geraniums III. Pennsylvania Flower Growers, University Park, $\mathrm{Pa}$
SAS Institute, Inc. 1985. SAS user's guide: Statistics. SAS Institute, Inc., Cary, N.C.

Steel, R.G.D. and J.H. Torrie. 1980. Principles and procedures of statistics. McGraw-Hill, New York.

Stephens, C.T. 1984. The glasshouse ornamental disease control handbook. Michigan State Univ. Ext. Bul. E-1750:29-30.
Stephens, C.T. and C.C. Powell. 1982. Pythium species causing damping-off of seedling bedding plants in Ohio greenhouses. Plant Dis. 66:731-733.

Stephens, C. T., L.J. Herr, A.F. Schmitthenner, and C.C. Powell. 1983. Sources of Rhizoctonia solani and Pythium spp. in a bedding plant greenhouse. Plant Dis. 67:272-275.

\title{
Influence of Photoperiod and Temperature on the Growth and Flowering of Heliconia aurantiaca
}

\author{
Vibeke Geertsen \\ Danish Research Service for Plant and Soil Science, Institute of \\ Glasshouse Crops, Aarslev DK-5792, Denmark
}

Additional index words. cut flower

Abstract. The effect of photoperiod $(8,12$, or $16 \mathrm{hr})$ and temperature $(15,18$, or $21 \mathrm{C})$ on Heliconia aurantiaca Ghiesbr. ex. Lemaire was investigated. By exposing plants to a photoperiod of $8 \mathrm{hr}$, flowering was more advanced and more abundant, fewer leaves subtended the inflorescence, and the length of the flowering stems was shorter than at $16 \mathrm{hr}$. Raising the temperature from 15 to $21 \mathrm{C}$ increased the flowering percentage by $\approx 20 \%$; the flowering stems were $40 \mathrm{~cm}$ longer and the number of leaves subtending the inflorescence was increased by 2.5 .

There is an increasing interest in Heliconias as cut flowers, landscaping plants for tropical regions, interior plants, and pot plants. Many species are very showy and have colorful inflorescences, but most are seasonal bloomers and produce few flowers.

Until now, very little has been known about manipulation of flowering in Heliconia. In $H$. psittacorum it has been reported that the main factors influencing flowering are irradiance and temperature (Broschat et al., 1984), but photoperiod also appears to have a slight influence (Geertsen, 1989).

In $H$. stricta, a seasonal pattern of flowering has been recorded. Yields were greater for plants grown at 8-hr photoperiods than under natural daylength (Criley and Kawabata, 1986). No flowering occurred in long days.

For $H$. aurantiaca it has been observed that under glasshouse conditions in Denmark flowering only occurs during November to February. This pattern suggests that flowering might be influenced by photoperiod. Since $H$. aurantiaca is an attractive plant

Received for publication 3 Jan. 1989. I wish to thank N. Bredmose for valuable discussions and correction of the manuscript, O. Bloch-Petersen and K.A. Kjaersgaard for technical assistance, and K. Kristensen for carrying out the statistical analyses. This research was partly funded by the Joint Committee for Agricultural Research and Experiments. The cost of publishing this paper was defrayed in part by the payment of page charges. Under postal regulations, this paper therefore mus be hereby marked advertisement solely to indicate this fact. that shows potential as a cut flower, particularly if flowering could be extended to a greater part of the year, the present experiment was set up to examine how photoperiod and temperature affect growth and flowering.

The experiment was carried out with $H$. aurantiaca that originally was obtained from the Botanical Garden in Edinburgh. Rhizome clumps with about three shoots (shoot length $<10 \mathrm{~cm}$, no unfolded leaves) were planted in 10-liter containers in February 1986. The potting medium was a well-drained Danish peat (Pindstrup 3). Until the start of the experiment on $10 \mathrm{Apr}$., plants were receiving natural daylength that varied from 10.5 to $14.5 \mathrm{hr}$, including civil twilight. The temperature was maintained at $20 \mathrm{C}$.

The experiment was carried out in the phytotron at the Institute of Glasshouse Crops. Plants were exposed to photoperiods of 8 , 12 , or $16 \mathrm{hr}$ combined with a minimum air temperature of 15,18 , or $21 \mathrm{C}$ (ventilation at $+3 \mathrm{C})$. The photoperiod treatments consisted of an 8-hr natural day in the glasshouse compartment plus day continuation by incandescent light in the dark chamber at a photon flux density of $3.5 \pm 1.9 \mu \mathrm{mol} \cdot \mathrm{s}^{-1} \cdot \mathrm{m}^{-2}$ to equal 12 or $16 \mathrm{hr}$. The actual average day temperatures in the glasshouse compartment were 20, 22, and 23C, respectively.

Each treatment consisted of nine plants that were spaced 14 plants $/ \mathrm{m}^{2}$. Treatments were terminated on 23 Oct.; from then on, plants were placed under natural daylength, which, in Denmark, is $\approx 12 \mathrm{hr}$ at the end of October, dropping to $8.5 \mathrm{hr}$ in midwinter, including 


\section{Number of leaves subtending the inflorescence}

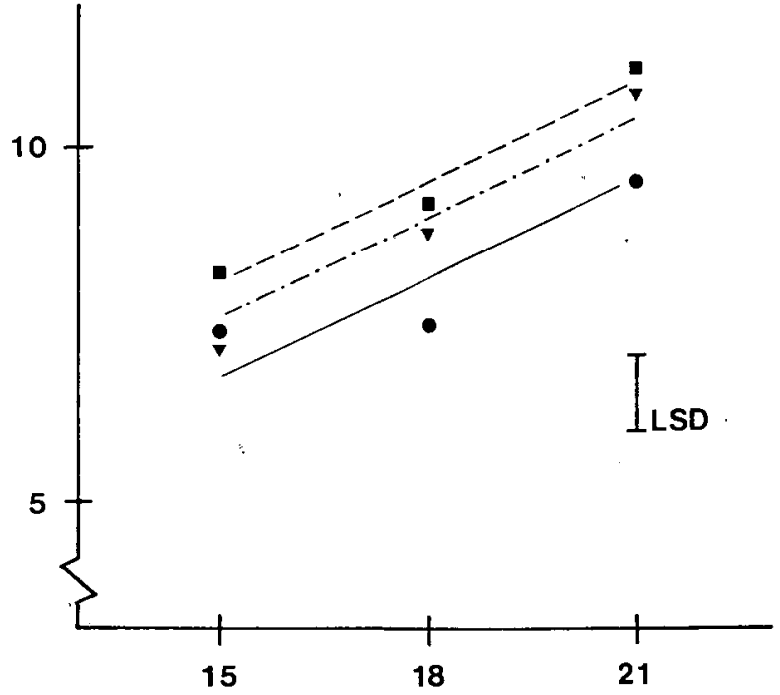

Temperature, $\mathrm{C}$

Fig. 1. The influence of photoperiod $(-\bullet-8 \mathrm{hr}, \cdots-\cdots, 12 \mathrm{hr},----16 \mathrm{hr})$ and temperature on number of leaves subtending the inflorescence of $H$. aurantiaca. Data were recorded on 7 Jan. The slope of the estimated lines is $7.0 \pm 0.9$. LSD $_{0.05}$ for comparison between two different daylengths at the same temperature level.

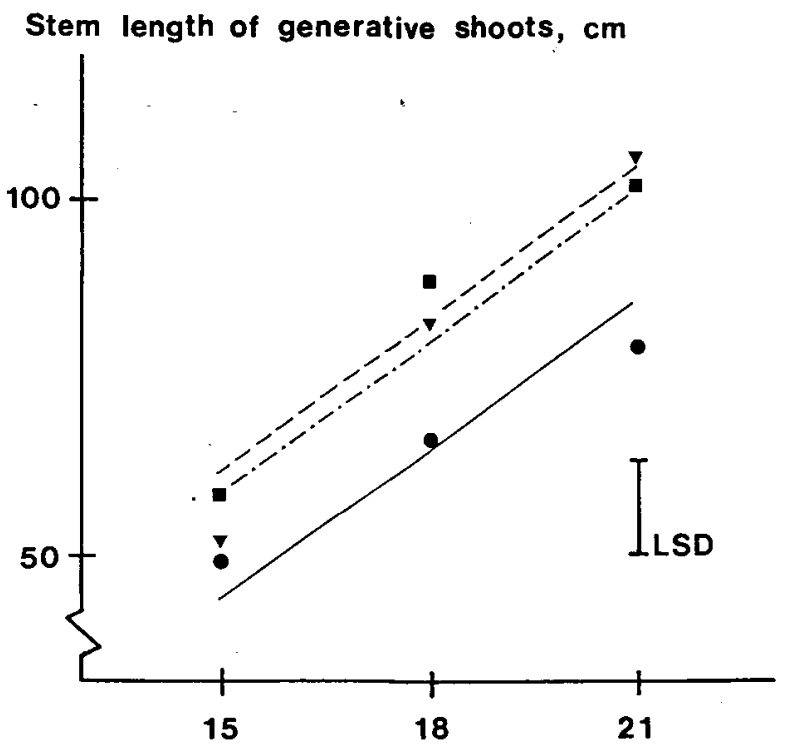

Temperature, $\mathbf{C}$

Fig. 2. Stem length of flowering shoots as influenced by temperature and photoperiod $(-\bullet-8 \mathrm{hr}$, $-\cdots-12 \mathrm{hr},---16 \mathrm{hr}$ ). Data were recorded on $7 \mathrm{Jan}$. The slope of the estimated lines is $0.5 \pm 0.1$. LSD $_{0.05}:$ text as Fig. 1 .

civil twilight. Temperature was held at 20C with ventilation at $+6 \mathrm{C}$. The experiment was terminated on 7 Jan.

Data recorded were number of vegetative and generative shoots, stem length of generative shoots, and number of leaves subtending the inflorescence. It was assumed that there was a linear relationship between temperature and the characters stem length of generative shoots and number of leaves subtending the inflorescence. Therefore, data were tested by using linear regression and analysis of variance (ANOVA). These analyses were chosen due to the limited plant number and lack of replications. For the characters of number of vegetative and generative shoots the assumption of linearity did not appear to be valid in the tested interval; therefore, those data have not been treated statistically.

Effects of temperature. Plants held at $15 \mathrm{C}$ until 24 Oct. produced a mean of 48 shoots (range 24 to 75 ), whereas those held at 18 or $21 \mathrm{C}$ produced $\approx 98$ (range 84 to 111 ). (data not shown).

On 7 Jan., when the experiment was terminated, the flowering percentage, defined as percentage of shoots per container with visible flower buds or developed inflorescences, was calculated. Flowering was $<40 \%$ (range 27 to 47) for plants grown at $15 \mathrm{C}$ and $60 \%$ (range 40 to 78 ) at $21 \mathrm{C}$. Also, plants grown at $21 \mathrm{C}$ had reached a more pronounced stage of floral development than plants grown at $15 \mathrm{C}$ (data not shown).

Fewer leaves subtended the inflorescence and plants were shorter when temperature was kept low. For plants grown at $15 \mathrm{C}$ a mean of 7.5 leaves subtended the inflorescence compared to 10 when plants were grown at $21 \mathrm{C}$ (Fig. 1). The stem length was 55 and $95 \mathrm{~cm}$, respectively (Fig. 2).

Effects of photoperiod When the treatment was terminated on 24 Oct. flowering was very sparse and only plants that had been subjected to a photoperiod of $8 \mathrm{hr}$ were flowering. From then on plants were placed under natural daylength until 7 Jan., when the experiment was ended. At this time, flowering occurred in all plots. The flowering percentage was on average $62 \%$ (range 47 to 78 ), $38 \%$ (range 27 to 40 ), and $46 \%$ (range 33 to 64) for plants subjected to photoperiods of 8,12 , or $16 \mathrm{hr}$, respectively.

When plants were subjected to a photoperiod of $8 \mathrm{hr}$, fewer leaves subtended the inflorescence than at $16 \mathrm{hr}$. There was no significant difference between 8 and $12 \mathrm{hr}$ or 12 and $16 \mathrm{hr}$ (Fig. 1). If the daylength was extended to 12 or $16 \mathrm{hr}$, as compared to $8 \mathrm{hr}$, the length of the flowering shoots was increased by 15 to $20 \mathrm{~cm}$. There was no significant difference between 12 and $16 \mathrm{hr}$ (Fig. 2).

Daylength had no major influence on the total number of shoots emerging.

The results suggest that flowering in $H$. aurantiaca can be advanced by exposing the plants to short days $(8 \mathrm{hr})$. During the treatment period, which was 28 weeks, flowering was very sparse. This result indicates that this period apparently was too short for the shoots to reach a stage where they were susceptible to a floral stimulus and to develop the inflorescence to anthesis.

For H. stricta it was reported that shoots had to have four leaves or more before flowering can be initiated (Criley and Kawabata, 1986). In $H$. psittacorum the flowering shoots normally have four to five leaves (Broschat et al., 1984), and in H. caribea and H. brasiliensis it was suggested that a constant number of leaves (five to seven) subtend the inflorescence (Criley, 1985). The present experiment showed that the inflorescence of $H$. aurantiaca was subtended by at least seven leaves (Fig. 1).

For $H$. stricta, the required period for development of the inflorescence to anthesis was reported to be about 13 weeks from the start of short day (Criley and Kawabata, 1986). In H. psittacorum a harvestable flower was produced 8 to 9 weeks after emergence of a shoot from the rhizome under optimum conditions (Broschat et al., 1984). The length of the period for floral development is unknown for $H$. aurantiaca.

Growth of $H$. aurantiaca was influenced by temperature. Plants grown at $18 \mathrm{C}$ produced more shoots than plants grown at $15 \mathrm{C}$, 
but a further rise in the temperature did not increase the shoot number, whereas $H$. psittacorum plants produced even more shoots at 21C (Geertsen, 1989). This result corresponds with the fact that $H$. aurantiaca is indigenous to areas with slightly cooler conditions than $H$. psittacorum: $H$. aurantiaca is found in southern Mexico to central Costa Rica up to an altitude of $800 \mathrm{~m}$, whereas $H$. psittacorum is found in the northern part of South America, just around the equator (Andersson, 1985).

According to the current results, the earliest flowering of $H$. aurantiaca is achieved when plants are exposed to short days (8 hr) and high temperature $(21 \mathrm{C})$. But the experiment raises new questions: 1) how many weeks of short days are necessary to initiate flowering; 2) is there a stage at which the stimulus is most effective; 3 ) does the period of exposure to short days have any influence on flowering characteristics; and 4) how long a period is necessary for floral development?

\section{Literature Cited}

Andersson, L. 1985. Revision of Heliconia subgen. Stenochlamys (Musaceae-Heliconioideae). Op- era Botanica 82: 1-124.

Broschat, T. K., H. Donselman, and A.A. Will. 1984. 'Andromeda' and 'Golden Torch' Heliconias. HortScience 19(5):736-737.

Criley, R.A. 1985. Heliconia, p. 125-128. In: A Halevy (ed.). Handbook of flowering. CRS, Boca Raton, Fla.

Criley, R.A. and O. Kawabata. 1986. Evidence for a short-day flowering response in Heliconia stricta 'Dwarf Jamaican'. HortScience 21(3):506-507.

Geertsen, V. 1989. Effect of photoperiod and temperature on the growth and flower production of Heliconia psittacorum 'Tay'. Acts Hort. 252:117-122. (In press.)

\title{
Chlormequat Chloride Growth Retardant Reduces Spider Mite Infestations of Hibiscus rosa-sinensis
}

\author{
L.S. Osborne ${ }^{1}$ and A.R. Chase ${ }^{2}$ \\ University of Florida, IFAS, Central Florida Research and Education \\ Center, 2807 Binion Road, Apopka, FL 32703
}

Additional index words. integrated pest management, CCC

\begin{abstract}
Hibiscus rosa-sinensis L. plants treated three times with $850 \mathrm{mg} \cdot \mathrm{liter}^{-1}$ of the growth retardant chlormequat chloride (CCC) were less susceptible to infestation with Tetranychus urticae (Koch) than water-treated control plants. The difference in mite numbers was noted within 8 days after releasing mites onto test plants. Mean number of mites per treated plant was 3.7, compared to 30 on nontreated plants. This activity was observed on all treated plants 6 months after applying CCC. Significant differences were observed on treated plants that were defoliated and allowed to produce new foliage before being evaluated. Therefore, surface chemical residues were not responsible for reducing mite infestations on CCC-treated plants.
\end{abstract}

Growth regulators are used on a wide variety of ornamental crops to improve rooting, increase shoot formation, shorten internodes, and induce flowering. The effects of some of these compounds on pests have been investigated on many crops. Chlormequat chloride (CCC) has been shown to suppress fecundity, feeding, survival, and population development of numerous aphid species (Tahori et al., 1965c; van Emden, 1964, 1969), Lepidoptera (Tahori et al., 1965b; Zummo et al., 1984), and the greenhouse whitefly (Fischer and Shanks, 1979). The action that CCC has on aphids may result from a decrease in the nutritive quality of treated plants (van Emden, 1969). Not all effects observed have been negative. Fischer and Shanks (1979) observed that whitefly infestations increased on the poinsettia variety 'Eckespoint

Received for publication 3 Oct. 1988. Published as Florida Agricultural Experiment Stations Journal Series no. 9572. The cost of publishing this paper was defrayed in part by the payment of page charges. Under postal regulations, this paper therefore must be hereby marked advertisement solely to indicate this fact.

'Associate Professor of Entomology.

${ }^{2}$ Professor of Plant Pathology.
C-1', even though a reduction was noted on 'Annette Hegg Lady'.

Grower observations regarding twospotted spider mite (TSM) populations on Hibiscus rosa-sinensis led to the study described here. Because obvious alterations in leaf appearance occur after CCC treatment and because TSM reacts to slight differences in leaf variegation or structure (Osborne and Chase, 1985), the potential for differential susceptibility of hibiscus to infestation by TSM exists. Effects of CCC treatment on infestations by TSM on hibiscus were evaluated.

Rooted cuttings were obtained from growers and established in potting medium consisting of equal volumes of steam-treated (90C for $1.5 \mathrm{hr}$ ) Canadian peat and pine bark. The medium was amended with $\left(\mathrm{kg} \cdot \mathrm{m}^{-3}\right) 3.6$ Osmocote 19:6:12 (slow-release fertilizer, Sierra Chemical, Milpitas, Calif.), 2.7 dolomite, and 0.5 Micromax micronutrient (Sierra Chemical). Plants were grown in 10$\mathrm{cm}$-diameter (0.8-liter) plastic pots in a glasshouse at 18 to $33 \mathrm{C}$ and maximum light level of $350 \mu \mathrm{mol} \cdot \mathrm{s}^{-1} \cdot \mathrm{m}^{-2}$. Unless otherwise noted, each test consisted of two treatments with 10 plants being treated with water only and 10 with CCC (American Cy - anamid, Wayne, N. J.) three times at weekly intervals starting no sooner than 3 weeks after potting. Chlormequat chloride was applied to runoff at the rate of $850 \mathrm{mg} \cdot$ liter $^{-1}$.

An initial study (Test 1) was conducted to test the hypothesis that CCC-treated hibiscus plants were less susceptible to mites than nontreated plants. Treatments were applied on 15, 22, and 29 May 1984. Plants were infested 2 days after the final treatment with five, 1- to 2-day-old adult female TSM per plant. After being infested, 10 treated and 10 control plants were randomized on a raised bench in a greenhouse. The numbers of active (motile) mites were counted 8 June 1984 (8 days after infestation).

A second study (Test 2) was conducted in order to validate the findings of Test 1 . Treatments were applied on 6, 13, and 20 July 1984. After each application, all 20 plants were randomized on a raised bench in a greenhouse infested with TSM and allowed to become naturally infested. This was done to better simulate a natural situation where mites are given an opportunity to select their own food source. No mites were observed on any plants before the final CCC application.

The number of motile mites on each plant was determined on 10 Aug. 1984. After this evaluation, plants were treated twice, with a 4-day interval with the labeled rates of the acaricide dienochlor (Pentac WP), inspected to ensure no mites were present, and then returned to the infested greenhouse. Thereafter, plants were monitored on 31 Aug. and 10 Sept. and the number of motile mites on each plant counted.

A third study (Test 3) was conducted to determine if $\mathrm{CCC}$ residues on the leaf surface were responsible for results observed in the two previous tests. Treatments were applied on 6, 13, and 20 July 1984 as described for the previous tests. Plants were defoliated by hand on 19 Sept. and allowed to produce new growth. On 6 Nov., three leaves/plant were infested with three 1-to 2-day-old adult female TSM/leaf. The numbers of motile mites were counted 14, 20, and 27 Nov.

The fourth study (Test 4) was conducted to determine if CCC activity had long-term effects. Treatments were applied to hibiscus on 13, 20, and 27 July 1984. On 10 Aug., 